\author{
Cezary Kochalski* \\ Tomasz M. Zieliński*
}

\title{
BADANIA NAD ZAAWANSOWANIEM RACHUNKÓW KOSZTÓW W SPÓŁKACH GIEŁDOWYCH W POLSCE
}

\section{WPROWADZENIE}

Spółki notowane na giełdzie, tak jak i inne przedsiębiorstwa, powinny mierzyć koszty tak, aby z punktu widzenia sprawozdawczego możliwa była wiarygodna wycena zapasów i ustalanie wyniku finansowego, a z punktu zarządczego, aby podejmowane decyzje bazowały na precyzyjnych informacjach kosztowych. Tylko wtedy rynek giełdowy będzie mógł poznać prawdziwe wyniki działalności spółki oraz przekonać się, co do zasadności podejmowanych działań, które zawsze wymagają poniesienia kosztów.

Celem opracowania jest rozpoznanie sytuacji co do stanu zaawansowania rachunku kosztów w spółkach giełdowych w Polsce. W badaniu podjęto się weryfikacji następujących hipotez: (1) spółki giełdowe w Polsce w większości stosują tradycyjne (sprawozdawcze) rachunki kosztów natomiast w zdecydowanie mniejszym stopniu wykorzystywane są nowoczesne koncepcje zarządczego rachunku kosztów, (2) spółki giełdowe osiągają wyższy poziom dojrzałości rachunku kosztów od pozostałych przedsiębiorstw.

\section{UZASADNIENIE PODJĘCIA TEMATU}

Spółki giełdowe są oceniane przede wszystkim przez pryzmat osiaganych wyników w danym okresie. W wypadku analizy fundamentalnej oceniający stara się rozstrzygnąć, czy „fundamenty” spółki giełdowej są solidne. Skoro nie ma działania, które nie pociągałoby za sobą konieczności uprzedniego poniesienia

\footnotetext{
* Uniwersytet Ekonomiczny w Poznaniu.

${ }^{* * *}$ Uniwersytet Ekonomiczny w Poznaniu.
} 
kosztów, to za ten fundament trzeba uznać zarządzanie kosztami, a więc zdolność przedsiębiorstwa do kształtowania wielkości i struktury kosztów pod kątem tworzenia wartości.

O tym, czy i w jakim stopniu ponoszone koszty przyczyniają się do tworzenia wartości w spółce giełdowej, powinien (a wręcz musi) informować rachunek kosztów. Musi być to rachunek, który umożliwia mierzenie kosztów w warunkach, gdy w spółkach giełdowych coraz większe znaczenie odgrywają koszty pośrednie, musi to być rachunek, który zwraca uwagę na koszty kapitału. A wiec, musi to być odpowiednio zaawansowany rachunek kosztów.

Rosnące koszty pośrednie oraz koszty kapitału są konsekwencją zmian w wielkości i strukturze zasobów, które są wykorzystywane w procesach wytwórczych i sprzedażowych współczesnych przedsiębiorstw dla dostarczania wartości klientom. Spółki giełdowe zmuszone są do inwestowania w nowoczesne technologie, logistykę oraz marketing. Chcąc zapanować nad zużywanymi i angażowanymi zasobami, spółki giełdowe powinny więc posługiwać się coraz bardziej zaawansowanym rachunkiem kosztów.

Spółki giełdowe powinny posługiwać się takim rachunkiem kosztów, który pozwoli na wiarygodną kalkulację, a przez to na poznanie, jaka jest prawdziwa rentowność produktów (klientów). Tylko wtedy będzie możliwe podejmowanie trafnych decyzji w przedsiębiorstwie, i tylko wtedy inwestorzy będą mogli mieć przesłanki do oceny wyników działalności spółki z punktu widzenia kreacji wartości. Jeżeli w spółce giełdowej nie stosuje się odpowiednio zaawansowanego rachunku kosztów, to nie można stwierdzić do końca, jaka jest faktyczna efektywność przedsiębiorstwa.

\section{POZIOMY ZAAWANSOWANIA RACHUNKU KOSZTÓW}

Przeprowadzenie badania nad zaawansowaniem rachunku kosztów w polskich spółkach giełdowych wymagało rozpoznania, zdefiniowania i przyjęcia określonej koncepcji hierarchizacji rachunków kosztów ${ }^{1}$. Jako podstawę odniesienia wykorzystaną do oceny stopnia dojrzałości rachunków kosztów stosowanych w spółkach giełdowych w Polsce przyjęto tzw. „Model 12 Poziomów Dojrzałości Rachunku Kosztów", który pierwotnie został zaprezentowany w publikacji (dotyczacej międzynarodowych wytycznych dobrych praktyk) o tytule „Ocena i doskonalenie rachunku kosztów w organizacjach” (Evaluating and

\footnotetext{
${ }^{1}$ Badania nad dojrzałością rachunków kosztów w polskich przedsiębiorstwach prowadzone są przez T. M. Zielińskiego w ramach przygotowywanej rozprawy doktorskiej na Uniwersytecie Ekonomicznym w Poznaniu pt.: „Zasobowo-Procesowy Rachunek Kosztów” pod opieką naukową C. Kochalskiego.
} 
Improving Costing in Organizations ${ }^{2}$ ) oraz w towarzyszącym tej publikacji dokumencie Evaluating the Costing Journey: A Costing Levels Continuum Maturity Model $^{3}$. Prace badawcze nad tym modelem i jego modyfikacją prowadzone są również na gruncie polskim ${ }^{4}$.

W rozpatrywanym modelu uszeregowania koncepcji rachunków kosztów dokonano przy uwzględnieniu dwóch kryteriów ${ }^{5}$ :

- możliwości prawidłowego modelowania kosztów, zarówno historycznych, jak i przyszłych oraz

- jakości informacji o kosztach krańcowych (marginalnych), jaką zapewnia dany rachunek kosztów.

Wyróżniono następujące poziomy zawansowania rachunku kosztów:

- Poziom 1 - koszty ujmowane są w wyłącznie w układzie rodzajowym bez podziałów na centra kosztów. Nie są prowadzone kalkulacje kosztów jednostkowych,

- Poziom 2 - koszty są ujmowane w centrach kosztów (wyodrębnianych dla działów i wydziałów). Kalkulacja kosztów jednostkowych, albo nie jest realizowana, albo wykorzystane są zasady kalkulacji podziałowej prostej,

- Poziom 3 - kalkulacja kosztu jednostkowego (pełnego) jest realizowana do poziomu grup produktowych/usługowych i jest ograniczona do kosztów bezpośrednich, które mogą być wprost przypisane do grup produktowych i usługowych,

- Poziom 4 - kalkulacja kosztu jednostkowego realizowana jest ze szczegółowością do poziomu grup produktowych/usługowych. Koszty pośrednie są doliczane jako arbitralny narzut kosztów w oparciu o tradycyjne klucze doliczeniowe, jak np. roboczogodziny, kilogramy, sztuki itp.,

- Poziom 5 - rachunek kosztów standardowych lub kalkulacja projektowa/zleceniowa. Kalkulacja kosztów jednostkowych wykonywana jest do poziomu poszczególnych produktów lub usług z uwzględnieniem arbitralnego narzutu kosztów pośrednich,

- Poziom 6 - rachunek kosztów działań (podejście klasyczne), w którym kalkulacja kosztów jednostkowych realizowana do poziomu poszczególnych produktów i usług,

- Poziom 7 - rachunek kosztów działań uwzględniający finalne alokowanie kosztów do produktów, a także do obiektów kosztowych klientów,

${ }^{2}$ IFAC, Evaluating and Improving Costing in Organizations, International Federation of Accountants, New York 2009, s. 23.

${ }^{3}$ IFAC, Evaluating the Costing Journey: A Costing Levels Continuum Maturity Model, International Federation of Accountants, New York 2009, s. 19.

${ }^{4}$ T. M. Zieliński, Model 12 Poziomów dojrzałości w kalkulacji kosztów, „Controlling i Rachunkowość Zarządcza” 2011, nr 5, 6, 9, 10, 11 i 12 (cykl 6 artykułów). Dalsze prace prowadzone są przez T. M. Zielińskiego w ramach przygotowywanej rozprawy doktorskiej na Uniwersytecie Ekonomicznym w Poznaniu pt.: „Zasobowo-Procesowy Rachunek Kosztów”.

${ }^{5}$ IFAC, Evaluating the Costing..., op. cit., s. 6. 
- Poziom 8a - rachunek kosztów działań (podejście klasyczne) lub rachunek kosztów standardowych $\mathrm{z}$ wyodrębnieniem szacunkowo określanych kosztów niewykorzystanych zasobów,

- Poziom 8b - resource consumption accounting (RCA) oparty na kosztach rzeczywistych oraz zasobowo-procesowy rachunek kosztów rzeczywistych (resource and process consumption accounting - RPCA), (GPK),

- Poziom 9 - activity based resource leanning, grenzplankostenrechnung

- Poziom 10 - rachunek kosztów działań sterowany czasem (time driven $\mathrm{ABC})$,

- Poziom 11 - resource consumption accounting (RCA), zasobowo-procesowy rachunek kosztów planowanych oraz standardowych (RPCA),

- Poziom 12 - nie ma konkretnie określonej koncepcji rachunku kosztów, dominują symulacje.

Zasadność przyjętej hierarchii w modelu 12 poziomów, wskazującej większe zaawansowanie rachunków kosztów planowanych od rachunków kosztów rzeczywistych, potwierdzana jest w światowej i polskiej literaturze przedmiotu ${ }^{6}$.

\section{METODYKA}

Metodyka przeprowadzonego badania była następująca:

- w badaniu uwzględniono dwie podstawowe grupy zmiennych: zmienne określające badaną spółkę oraz zmienną charakteryzujące poziom dojrzałości stosowanego rachunku kosztów;

- badanie przeprowadzono w formie ankiety, którą objęto 574 osoby. Zwrotnie uzyskano 360 wypełnionych ankiet, z których 221 poddano analizie. Usunięto te ankiety, które zostały wypełnione niekompletnie, oraz te, które odnosiły się do tych samych przedsiębiorstw. Odsetek poprawnie wypełnionych ankiet wyniósł 38,5\%. Wysoki odsetek wypełnionych ankiet wynika z przyjętej koncepcji jego przeprowadzania i bezpośredniego kontaktu z respondentami;

- mając na uwadze niski stopień rozpowszechnienia nowoczesnych rachunków kosztów w Polsce ${ }^{7}$ oraz niewielki stopień znajomości nowoczesnych koncepcji rachunku kosztów przez menedżerów i pracowników przedsiębiorstw,

${ }^{6}$ B. D. Clint o n, A. van der Merwe, Management Accounting Approaches, Techniques and Management Processes, „Cost Management”, May/June 2006, s. 16; R. Cooper, R. S. Ka plan, Zarzadzanie kosztami i efektywnościa, tłum. I. Podsiadło, B. Święcicka, Oficyna Ekonomiczna, Kraków 2000, s. 29; E. N o w a k, M. W i e r z biń s ki, Rachunek kosztów - modele i zastosowania, PWE, Warszawa 2010, s. 19; G. Świders ka (red.), Controlling kosztów i rachunkowość zarzadcza, Difin, Warszawa 2010, s. 284.

${ }^{7}$ T. W n u k-P e l, Zastosowanie rachunku kosztów dziatań w przedsiębiorstwach w Polsce, Wydawnictwo Uniwersytetu Łódzkiego, Łódź 2011, s. 179. 
zrezygnowano z koncepcji rozsyłania ankiet do przedsiębiorstw za pośrednictwem poczty. O wypełnienie ankiet poproszono uczestników konferencji controllingowych kierowanych do menedżerów, właścicieli, controllerów oraz księgo$\mathrm{wych}^{8}$;

- w całej populacji badanych przedsiębiorstw nieco ponad $12 \%$ to przedsiębiorstwa notowane na Giełdzie Papierów Wartościowych w Warszawie. Pozostałe (około 88\%) stanowiły przedsiębiorstwa nienotowane na giełdzie;

- ankiety miały na celu pozyskanie informacji na temat wielkości przychodów, struktury własnościowej, liczby zatrudnionych osób, branży oraz faktu notowania na GPW w Warszawie oraz wskazanie poziomu dojrzałości rachunku kosztów;

- ankiety zostały zweryfikowane pod kątem wzajemnej zgodności. Do przeprowadzenia badania wykorzystano zarówno analizę opisową, jak i testy statystyczne;

- w analizie opisowej użyto takie miary statystyki opisowej, jak: mediana, minimum, maksimum, dolny kwartyl, górny kwartyl. Pomimo, że jest to skala porządkowa to dla celów informacyjnych i poglądowych wyznaczono: średnią arytmetyczną, odchylenie standardowe;

- do porównań wyników dla spółek notowanych i nienotowanych na GPW w Warszawie zastosowano test nieparametryczny U Manna-Whitneya dedykowany skali porządkowej.

\section{ANALIZA UZYSKANYCH WYNIKÓW}

Tabela 1 przedstawia statystyki opisowe badania poziomów dojrzałości rachunków kosztów w spółkach giełdowych w Polsce w latach 2011-2012.

W wypadku obu grup przedsiębiorstw średnia pozycyjna (mediana) jest taka sama i wynosi 5. Jednakże $75 \%$ przedsiębiorstw z notowanych na GPW w Warszawie oceniło poziom dojrzałości swojego rachunku kosztów na poziomie 5 lub wyższym, a $25 \%$ z tych przedsiębiorstw deklaruje stosowanie rachunku kosztów na poziomie 7 lub wyższym.

W wypadku przedsiębiorstw nie notowanych na GPW w Warszawie, aż $75 \%$ przedsiębiorstw deklaruje wykorzystywanie rachunku kosztów na poziomie 5 lub niższym (tradycyjny rachunek kosztów). Jednocześnie połowa nienotowanych przedsiębiorstw realizuje rachunek kosztów na poziomie 4 lub 5.

\footnotetext{
${ }^{8}$ Konferencje pt: „Jak prawidłowo kalkulować i rozliczać koszty na produkty i klientów przedsiębiorstwa”, 2011-05-13 Wrocław, 2011-05-30 Katowice, 2011-06-04 Łódź, 2011-06-27 Poznań, 2011-06-28 Warszawa, 2011-09-26 Gdańsk, 2011-10-12 Katowice, 2011-10-24 Warszawa, 2012-04-16 Poznań, 2012-05-22 Katowice, 2012-05-28 Warszawa, Organizator: ABC Akademia Sp. z o.o.
} 
Tabela 1

Statystyki opisowe poziomu dojrzałości rachunku kosztów - w podziale na przedsiębiorstwa notowane i nienotowane na GPW w Warszawie (lata 2011-2012)

\begin{tabular}{|l|c|c|c|c|c|c|c|c|}
\hline \multirow{2}{*}{ Wyszczególnienie } & \multicolumn{8}{|c|}{ Poziom dojrzałości } \\
\cline { 2 - 10 } & średnie & ważnych & odch.std & minimum & maksimum & Q25 & mediana & Q75 \\
\hline $\begin{array}{l}\text { Nienotowane na } \\
\text { GPW w Warszawie }\end{array}$ & 4,84 & 194 & 1,69 & 1 & 9 & 4 & 5 & 5 \\
\hline $\begin{array}{l}\text { Notowane na GPW } \\
\text { w Warszawie }\end{array}$ & 5,96 & 27 & 2,24 & 1 & 12 & 5 & 5 & 7 \\
\hline Razem & 4,97 & 221 & 1,80 & 1 & 12 & 4 & 5 & 6 \\
\hline
\end{tabular}

Źródło: opracowano na podstawie wyników badania ankietowego przeprowadzonego w latach 2011-2012.

Rysunek $1 \mathrm{i}$ tab. 2 przedstawiają rozkład poziomów dojrzałości rachunku kosztów w badanych przedsiębiorstwach i pozwalają ocenić skalę stosowania różnych koncepcji rachunku kosztów w ujęciu przedsiębiorstw notowanych na GPW oraz pozostałych.

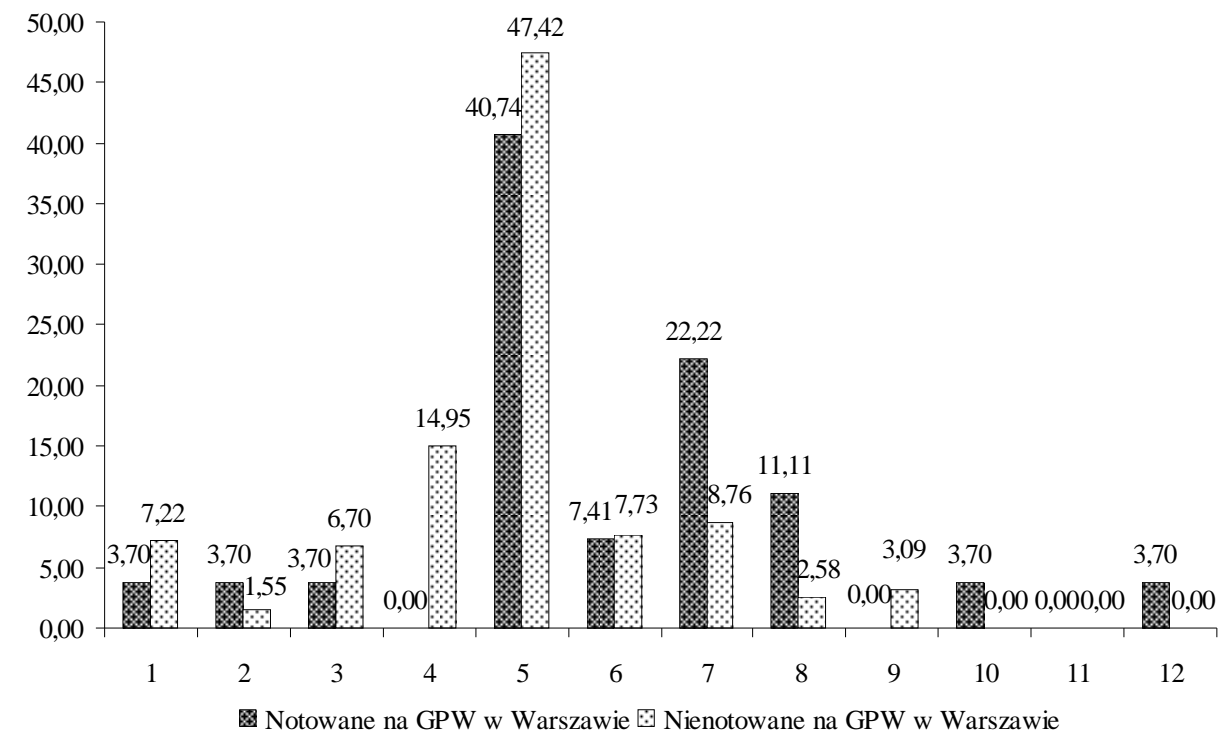

Rys. 1. Poziom dojrzałości rachunku kosztów w polskich przedsiębiorstwach

- w podziale na notowane i nienotowane na GPW (lata 2011-2012)

Źródło: opracowanie na podstawie wyników badania ankietowego przeprowadzonego w latach 2011-2012. 
Najbardziej „,popularnym” rachunkiem kosztów, zarówno w przedsiębiorstwach notowanych jak i nienotowanych na giełdzie, jest rachunek kosztów klasyfikowany na poziomie 5 (tradycyjny rachunek kosztów z arbitralnymi narzutami kosztów - rachunek kosztów standardowych lub kalkulacja projektowa/zleceniowa). Rachunek poziomu 5 wskazało ponad $40 \%$ przedsiębiorstw notowanych na giełdzie w porównaniu do ponad $47 \%$ przedsiębiorstw nienotowanych na GPW w Warszawie.

Ogółem stosowanie tradycyjnych, sprawozdawczych rachunków kosztów (poziomy 1-5) wskazuje ponad 51\% przedsiębiorstw notowanych na GPW w Warszawie, co potwierdza postawioną w badaniu hipotezę, że większość spółek giełdowych stosuje tradycyjne rachunki kosztów. Podkreślić należy, że w porównaniu do pozostałych spółek, gdzie poziomy $1-5$ stosuje prawie $78 \%$, to spółki giełdowe w jednak większym stopniu wykorzystują nowoczesne rachunki kosztów.

Tabela 2

Poziom dojrzałości rachunku kosztów w polskich przedsiębiorstwach - w podziale na notowane i nienotowane na GPW (lata 2011-2012)

\begin{tabular}{|c|c|c|c|c|}
\hline \multirow{2}{*}{ Poziom dojrzałości } & \multicolumn{2}{|c|}{$\begin{array}{c}\text { Notowana na GPW } \\
\text { w Warszawie }\end{array}$} & \multicolumn{2}{c|}{ Nienotowana } \\
\cline { 2 - 5 } & $\%$ & \% skum. & $\%$ & \% skum. \\
\hline \hline 1 & 3,70 & 3,70 & 7,22 & 7,22 \\
\hline 2 & 3,70 & 7,41 & 1,55 & 8,76 \\
\hline 3 & 3,70 & 11,11 & 6,70 & 15,46 \\
\hline 4 & 0,00 & 11,11 & 14,95 & 30,41 \\
\hline 5 & 40,74 & $\mathbf{5 1 , 8 5}$ & 47,42 & $\mathbf{7 7 , 8 4}$ \\
\hline 6 & 7,41 & 59,26 & 7,73 & 85,57 \\
\hline 7 & 22,22 & 81,48 & 8,76 & 94,33 \\
\hline 8 & 11,11 & $\mathbf{9 2 , 5 9}$ & 2,58 & $\mathbf{9 6 , 9 1}$ \\
\hline 9 & 0,00 & 92,59 & 3,09 & 100,00 \\
\hline 10 & 3,70 & 96,30 & 0,00 & 100,00 \\
\hline 11 & 0,00 & 96,30 & 0,00 & 100,00 \\
\hline 12 & 3,70 & 100,00 & 0,00 & 100,00 \\
\hline Razem & 100,00 & & 100,00 & \\
\hline & & & & \\
\hline
\end{tabular}

Źródło: jak do tab. 1.

Tradycyjne rachunki kosztów są skoncentrowane na sprawozdawczości zewnętrznej, a przez to $\mathrm{w}$ znacznym stopniu ignorują coraz bardziej precyzyjne potrzeby informacyjne kadry zarządzającej. Według wielu autorów założenia, jakie towarzyszyły wypracowywaniu tradycyjnych rachunków kosztów uległy, a przynajmniej ulegają dezaktualizacji ze względu na założenia merytoryczne 
i arbitralność podejścia ${ }^{9}$. Nadto, mając na uwadze nowoczesny nurt zarządzania przedsiębiorstwami pod kątem tworzenia wartości, również krytycznie ocenia się tradycyjną analizę kosztów wskazując, że nie spełnia ona oczekiwań tego nowoczesnego nurtu zarządzania ${ }^{10}$.

Dane tab. 2 wskazują, że prawie $41 \%$ spółek notowanych na giełdzie deklaruje stosowanie rachunków kosztów poziomów 6-8, w tym najwięcej, bo ponad $22 \%$ wskazań tyczy się poziomu 7 (rachunek kosztów koncentrujący się na kalkulacji kosztów obsługi i analizie rentowności klientów). Wynik ten może zostać zinterpretowany jako pozytywny kierunek związany z koncentracją spółek giełdowych na klientach i zarządzaniu ich rentownością. Spośród pozostałych przedsiębiorstw nieco ponad $19 \%$ wskazało na poziomy $6-8$, w tym prawie $9 \%$ również na poziom 7.

Porównując obie grupy przedsiębiorstw w zakresie wskazań poziomu 8, gdzie uplasowany jest rachunek kosztów wyodrębniający koszty niewykorzystanych zasobów, to wyraźnie więcej spółek giełdowych $(11,11 \%)$ wskazuje ten poziom, w porównaniu do $2,58 \%$ przedsiębiorstw pozostałych. Pomimo wyraźnej różnicy pomiędzy porównywanymi grupami przedsiębiorstw w zakresie wyodrębniania kosztów niewykorzystanych zasobów w rachunku kosztów, to jednak należy zwrócić uwagę, że podejście to jest w niewielkim stopniu stosowane w polskich przedsiębiorstwach. Brak wyodrębniania kosztów niewykorzystanych zasobów grozi występowaniem zjawiska spirali śmierci kosztów stałych, które polega na nieświadomym i nieuzasadnionym alokowaniu kosztów niewykorzystanych zasobów do produktów i klientów ${ }^{11}$. Deklarowany przez spółki giełdowe niewielki odsetek rachunków kosztów wyodrębniających koszty niewykorzystanych zasobów, stawia pytanie o spełnianie przez te przedsiębiorstwa wymogów sprawozdawczości zewnętrznej, która podkreśla konieczność wyodrębniania nieuzasadnionej części kosztów pośrednich oraz o jakość zarządzania kosztami pod kątem tworzenia wartości, wszak utrzymywaniu większej wielkości zasobów towarzyszą wyższe koszty kapitału.

W przypadku rachunków kosztów planowanych (poziomy 9-12), to spółki giełdowe w większym stopniu stosują te koncepcje (7,4\% wskazań) w porównaniu do 3,09\% w przedsiębiorstwach pozostałych. Niezależnie od liczby wskazań, uznać należy, że w porównaniu chociażby do przedsiębiorstw niemieckich, wynik polskich spółek giełdowych jest niski. Według badań prowadzonych na gruncie niemieckim, miedzy $50-60 \%$ przedsiębiorstw stosuje koncepcję wska-

${ }^{9}$ C. Kochalski, Koszty w przedsiębiorstwie zarzadzanym przez wartość - ujęcie modelowe, Wydawnictwo Akademii Ekonomicznej w Poznaniu, Poznań 2006, s. 13; G. Świderska, op. cit., s. 28; R. Cooper, R. S. Ka pl a n, op. cit., s. 19.

${ }^{10}$ C. Kochals ki, op. cit., s. 13.

${ }^{11}$ D. E. Keys, A. van der Merwe, The case for RCA: Understanding Resource Interrelationships, „Journal of Cost Management”, September/October 2001, vol. 15, no. 6, s. 28; T. M. Zi elińs ki, As Easy AS ABC - kalkulacja kosztów niewykorzystanych zasobów, „Controlling i Rachunkowość Zarządcza” 2007, nr 8, s. 97. 
zaną jako poziom 9 - grenzplankostenrechnung $(\mathrm{GPK})^{12}$, podczas gdy żadna ze spółek giełdowych nie wskazała tego poziomu.

Kolejnym elementem badania dojrzałości rachunków kosztów w spółkach giełdowych jest wykonanie statystycznego porównania z pozostałymi przedsiębiorstwami. Do porównania tych dwóch grup przedsiębiorstw zastosowano test U Manna-Whitneya, który okazał się istotny statystycznie $(\mathrm{p}=0,0025)$ i wykazał różnicę między przedsiębiorstwami z notowanymi i nienotowanymi na GPW (wyniki testu w tab. 3).

Tabela 3

Wyniki testu U Manna-Whitneya - w podziale na notowane i nie notowane na GPW (lata 2011-2012)

\begin{tabular}{|c|c|c|c|c|c|c|c|c|c|}
\hline \multirow{3}{*}{ Zmienna } & \multicolumn{9}{|c|}{$\begin{array}{l}\text { Test U Manna-Whitneya, względem zmiennej: notowana na GPW w Warszawie, } \\
\text { zaznaczone wyniki są istotne z } \mathrm{p}<, 05000\end{array}$} \\
\hline & Sum. rang & Sum. rang & $U$ & $Z$ & $p$ & $Z$ & $p$ & $N$ ważn. & $N$ ważn. \\
\hline & $\begin{array}{c}\text { notowana na } \\
\text { GW } \\
\text { w Warszawie }\end{array}$ & $\begin{array}{c}\text { nienotowana } \\
\text { na GPW } \\
\text { w Warszawie }\end{array}$ & & & & popraw. & & $\begin{array}{l}\text { notowana na } \\
\text { GPW } \\
\text { w Warszawie }\end{array}$ & $\begin{array}{c}\text { nienotowana } \\
\text { na GPW } \\
\text { w Warszawie }\end{array}$ \\
\hline $\begin{array}{c}\text { Poziom } \\
\text { dojrzałości }\end{array}$ & 3887,5 & 20643,5 & 1728,5 & 859048 & 0,004249 & 3,02329 & 0,0025 & 27 & 194 \\
\hline
\end{tabular}

Źródło: jak do tab. 1.

Zarówno analiza statystyk opisowych jak i wyniki testu statystycznego wykazały, że przedsiębiorstwa notowane na GPW w Warszawie mają istotnie wyższy poziom dojrzałości rachunków kosztów od przedsiębiorstw nienotowanych na giełdzie. Powyższe potwierdza przyjętą hipotezę, że spółki notowane na giełdzie osiągają wyższy poziom dojrzałości rachunku kosztów.

Większy stopień wykorzystania nowoczesnych rachunków kosztów przez spółki giełdowe sprawia, że są one bardzie predystynowane do prowadzenia w niedalekiej przyszłości rachunków kosztów określanych jako najbardziej zaawansowane np. zasobowo-procesowy rachunek kosztów (RPCA), resource consumption accounting (RCA), TD ABC czy grenzplankostenrechnung (GPK).

\section{UWAGI KOŃCOWE}

W opracowaniu wykazano, że spółki giełdowe w Polsce w większym stopniu wykorzystują nowoczesne rachunki kosztów w porównaniu z pozostałymi przedsiębiorstwami. Chociaż ciagle najbardziej „,popularnymi” są tradycyjne rachunki kosztów, spółki giełdowe zmierzają w kierunku stosowania rachunków

${ }^{12}$ W. Kilger, J. R. Pampel, K. Vikas, Introduction: Marginal Costing as a Management Accounting Tool, „Management Accounting Quarterly” 2004, vol. 5, no. 2, s. 15. 
kosztów, które z jednej strony dostarczą informacji o kosztach i rentowności klientów, a z drugiej uwypuklą aspekt kosztów niewykorzystanych zasobów, które pociągają za sobą niepotrzebne koszty kapitału. Podejście to może być wyjaśnione dążeniem do maksymalizacji wartości spółek poprzez dążenie do generowania zysku ze współpracy z poszczególnymi klientami przy jednoczesnym minimalizowaniu zaangażowanego kapitału i unikaniu ponoszenia kosztów niewykorzystanych zasobów.

\section{BIBLIOGRAFIA}

Clinton B. D., van der Merwe A., Management Accounting Approaches, Techniques and Management Processes, „Cost Management”, May/June 2006.

Cooper R., Kaplan R. S., Zarzadzanie kosztami $i$ efektywnościa, tłum. I. Podsiadło, B. Święcicka, Oficyna Ekonomiczna, Kraków 2000.

IFAC, Evaluating and Improving Costing in Organizations, International Federation of Accountants, New York 2009.

IFAC, Evaluating the Costing Journey: A Costing Levels Continuum Maturity Model, International Federation of Accountants, New York 2009.

Ke ys D. E., van der Merwe A., The case for RCA: Understanding Resource Interrelationships, ,Journal of Cost Management”, September/October 2001, vol. 15, no. 6.

Kilger W., Pampel J. R., Vikas K., Introduction: Marginal Costing as a Management Accounting Tool, ,Management Accounting Quarterly” 2004, vol. 5, no. 2.

Kochalski C., Koszty w przedsiębiorstwie zarzadzanym przez wartość - ujęcie modelowe, Wydawnictwo Akademii Ekonomicznej w Poznaniu, Poznań 2006.

Nowak E., Wi erzbiński M., Rachunek kosztów - modele $i$ zastosowania, PWE, Warszawa 2010.

Ś wi d ers k a G. (red.), Controlling kosztów i rachunkowość zarzq̨dzza, Difin, Warszawa 2010.

W n u k-P e 1 T., Zastosowanie rachunku kosztów dziatań $w$ przedsiębiorstwach $w$ Polsce, Wydawnictwo Uniwersytetu Łódzkiego, Łódź 2011.

Zi elińs ki T. M., As Easy AS ABC - kalkulacja kosztów niewykorzystanych zasobów, „Controlling i Rachunkowość Zarządcza” 2007, nr 8.

Zi elińs ki T. M., Model 12 Poziomów dojrzatości w kalkulacji kosztów, „Controlling i Rachunkowość Zarządcza” 2011, nr 5, 6, 9, 10, 11 i 12 (cykl 6 artykułów).

Cezary Kochalski

Tomasz M. Zieliński

\section{RESERACH INTO THE MATURITY OF COST ACCOUNTING IN THE LISTED POLISH COMPANIES}

The aim of the research is to recognize the situation as to the maturity of cost accounting in listed companies in Poland. The study verified the following hypotheses (1) listed companies in Poland mostly use traditional cost accounting while in a far lesser extent they use modern concepts of managerial cost accounting (2) companies listed on the Stock Exchange in Warsaw reach a higher level of maturity of cost accounting from other companies in Poland.

Key words: cost accounting, listed companies, controlling, management accounting. 